\title{
Effect of aluminum and chromium on the germination and growth of two Vigna species
}

\author{
${ }^{1}$ S. N. Jamal, ${ }^{1}$ M.Zafar Iqbal and ${ }^{2}$ M. Athar \\ ${ }^{1}$ Department of Botany, University of Karachi, Karachi, Pakistan \\ ${ }^{2}$ California Department of Food and Agriculture, Sacramento, USA
}

Received 29 December 2005;

revised 7 February 2006;

accepted 3 March 2006

available online 18 April 2006

\begin{abstract}
The study deals with the effect of metal toxicity (aluminum, chromium and combination of both the metals) on seed germination, root length, shoot length, seedling length and dry biomass of Vigna radiata and V. sinensis. Chromium adversely affected the seedling by significantly reducing the growth whereas aluminum did not show such effect in both the species. Percentage of germination was good in both the species at different concentration of treatment (aluminum, chromium and combined treatment). Shoot length was also not much affected in $V$. sinensis as it was greatly inhibited in $V$. radiata. Both the species showed the purpling of stem. Dry biomass of $V$. radiata showed positive effect than $V$. sinensis. However, dry biomass decreased to a lesser extent when treated with aluminum, chromium and combined treatment as compared to control.
\end{abstract}

Key words: Aluminum, chromium, Vigna spp., seedling growth, toxicity

*Corresponding Author, E-mail: atariq@cdfa.ca.gov

\section{INTRODUCTION}

The mutual interaction of metals is very important for plant growth and development and to determine the availability of metal ions under different soil conditions, such as $\mathrm{pH}$. Soil chemical factors that limit root growth in acid soil diminish crop production; include aluminum, chromium, manganese and various cations and also deficiency and unavailability of Ca, Mg, P, Mo and Si. These effects are further complicated by the interaction of $\mathrm{Al}$ with other ions in different plant genotypes and under stress conditions (Foy, 1992). Cytotoxicity of aluminum has been well documented in plants (Delhaize and Ryan, 1995; Horst et al., 1999; Kollmeier et al., 2000; Marienfeld et al., 2000). It is generally known that plants grown in acid soils due to aluminum solubility at low $\mathrm{pH}$ have reduced the root system and exhibit a variety of nutrient deficiency symptoms, with a consequence of decrease in yield. Aluminum toxicity is an intensively studied agricultural problem in countries having acid soils which constitute about $40 \%$ of world arable soils (LeNoble, 1996). Neogy et al., (2002) have found that aluminium toxicity is a major deterrent for plant growth in acid soils below pH 5.0. Rana and Aery (1999) studied the effect of aluminium in mustard, cowpea and wheat. Seed germination, early seedling growth and chlorophyll contents showed a decrease while soluble leaf protein and total phenol contents of test plants showed an increase over the control. Joshi et al., (1999) raised Vigna unguiculata plants in pots filled with sandy loam soil and treated with 0, 1, 2, 4 and $6 \mu \mathrm{gr}$ (VI)/gm of soil. In general, shoot length, root length, leaf area, fresh and dry mass of leaves, shoot and roots increased in $1 \mathrm{ppm}$ $\mathrm{Cr}(\mathrm{VI})$ treated plant and decreased thereafter upto 6 ppm Cr (VI). Subramani et al., (1997) studied the impact of fertilizer factory effluent on morphometrical and biochemical changes of $V$. unguiculata. The effluents from many industries are either transported to canal/ river through surface drains or allowed to spread near agricultural land. According to a rough estimate, 9000 million gallons of wastewater are daily discharged into water bodies from industrial sector (Saleemi 1993).

The farmers often use these effluents as a source of irrigation when there is a shortage of water. The heavy metals like aluminum, cadmium, chromium, copper, manganese, nickel and zinc in industrial effluents tend to accumulate in the soil. In addition to the soil contamination, a significant toxic chemical can be taken up by the crop and enters the food chain (Pescod and Alkaska, 1985). The present study was aimed at assessing the effect of aluminum and chromium individually and in combined together on seed germination and seedling growth of Vigna radiata and V. sinensis. 


\section{MATERIALS AND METHODS}

The seeds of Vigna radiata and Vigna sinensis were surface sterilized with a dilute solution of sodium-hypochloride (1.2\%). Aluminum was applied as aluminum nitrate $\mathrm{Al}\left(\mathrm{NO}_{3}\right)_{3}$ while chromium was used as potassium dichromate $\mathrm{K}_{2} \mathrm{Cr}_{2} \mathrm{O}_{7}$. The concentrations were 40, 80, 120 and 160 ppm while control was without aluminum and chromium. Fifteen seeds were placed in each petri plates. Seeds were germinated in the dark in petri dishes with $3 \mathrm{~mL}$ aluminum and chromium solution applied singly and in combined form. The seeds were considered germinated with the emergence of radicles. The germinated seeds were then transferred to 10/14 hour day and night period, respectively with temperature regime of $31 \pm 2{ }^{\circ} \mathrm{C}$. The average relative humidity was $75 \%$ as recorded by Sling psychrometer in the laboratory. All the growth experiments were provided with 160-watt light. Root, shoot and seedling length of three of the tallest seedlings were measured after 10 days and their dry weight recorded after drying in an oven at $80{ }^{\circ} \mathrm{C}$ for 24 hours. Data were analyzed statistically by ANOVA and Duncan's multiple range tests (Sokal and Rohlf , 1995).

\section{RESULTS}

Heavy metals supplied did not affect the percentage of germination of both Vigna species. Seeds of both the species germinated within few days showing 100 $\%$ germination (Tables 1-6). Root length of V. radiata treated with aluminum solution was not inhibited whereas seeds treated with chromium and combined treatment showed inhibition as compared with control. In aluminum treatment, length of the root increased as concentration increased whereas, in chromium and combined treatment, length of root decreased as concentration increased. Overall, chromium showed greater effect than combined treatment and aluminum. The concentration of aluminum applied to $V$. sinensis seedling showed reduction in root length with increase in concentration and the root length stunted as compared with control. Similar effect was found in chromium and combined treatment as shown in Tables 5 and 6. As the concentration was increased, the length of root decreased. Not much effect of heavy metals was found on shoot growth. Similar case was found in chromium and combined treatment but the length was not much promoted by chromium as it was enhanced by aluminium at all concentrations. In V. radiata, aluminum treatment showed better growth than chromium and combined treatment whereas the growth was greatly decreased as compared with control. Seedling length of both the species was not much affected by aluminum treatment as compared to control; it decreased with increasing concentration of metal. However, chromium inhibited the seedling length. In combined treatment the seedling length was affected as compared to control but there was reduction in length at all concentrations (Tables 1-6). Only aluminum showed overall enhanced effect whereas chromium and combined treatment showed inhibitory effect which was more pronounced in chromium. From the data it has been found that there was little effect of aluminum and chromium on dry weight of plants. Dry weights were increased with the increase in concentration at all given treatments but the growth was mostly promoted in aluminium treatment in $V$. radiate (Tables 1-6).

Table 1: Effects of aluminum on germination and growth of Vigna radiata

\begin{tabular}{ccccccc}
\hline Treatments & $\begin{array}{c}\text { Conc. } \\
(\mathrm{ppm})\end{array}$ & $\begin{array}{c}\text { Germination } \\
\%\end{array}$ & $\begin{array}{c}\text { Root Length } \\
(\mathrm{cm})\end{array}$ & $\begin{array}{c}\text { Shoot Length } \\
(\mathrm{cm})\end{array}$ & $\begin{array}{c}\text { Seedling Length } \\
(\mathrm{cm})\end{array}$ & $\begin{array}{c}\text { Dry Biomass } \\
(\mathrm{mg})\end{array}$ \\
\hline Control & 00 & $100 \pm 0 \mathrm{a}$ & $9.67 \pm 2.25 \mathrm{a}$ & $8.23 \pm 1.68 \mathrm{ab}$ & $17.90 \pm 1.23 \mathrm{ab}$ & $13.0 \pm 0.0 \mathrm{a}$ \\
& 40 & $100 \pm 0 \mathrm{a}$ & $10.58 \pm 0.27 \mathrm{a}$ & $8.67 \pm 0.27 \mathrm{~b}$ & $19.26 \pm 1.40 \mathrm{ab}$ & $17.3 \pm 1.3 \mathrm{a}$ \\
& 80 & $96 \pm 3 \mathrm{a}$ & $13.32 \pm 1.34 \mathrm{a}$ & $8.45 \pm 1.34 \mathrm{ab}$ & $21.77 \pm 1.55 \mathrm{~b}$ & $15.0 \pm 1.0 \mathrm{a}$ \\
$\mathrm{Al}$ & 120 & $100 \pm 0 \mathrm{a}$ & $11.72 \pm 1.53 \mathrm{a}$ & $6.32 \pm 1.53 \mathrm{ab}$ & $18.04 \pm 1.82 \mathrm{ab}$ & $15.3 \pm 2.3 \mathrm{a}$ \\
& 160 & $100 \pm 0 \mathrm{a}$ & $11.12 \pm 0.49 \mathrm{a}$ & $5.16 \pm 0.49 \mathrm{a}$ & $16.28 \pm 0.35 \mathrm{a}$ & $17.3 \pm 1.3 \mathrm{a}$ \\
\hline
\end{tabular}

Statistical analysis determined by ANOVA. Figs. followed by the same letters in the same column are not significantly different at $\mathrm{P}<0.05$ (Duncan Multiple Range Test).

\pm Standard Error 
Table 2: Effects of chromium on germination and growth of Vigna radiata

\begin{tabular}{|c|c|c|c|c|c|c|}
\hline Treatments & $\begin{array}{l}\text { Conc. } \\
(\mathrm{ppm})\end{array}$ & $\begin{array}{c}\text { Germination } \\
\% \\
\end{array}$ & $\begin{array}{l}\text { Root length } \\
(\mathrm{cm})\end{array}$ & $\begin{array}{l}\text { Shoot length } \\
(\mathrm{cm})\end{array}$ & $\begin{array}{l}\text { Seedling length } \\
(\mathrm{cm})\end{array}$ & $\begin{array}{c}\text { Dry biomass } \\
\text { (mg) }\end{array}$ \\
\hline \multirow[t]{2}{*}{ Control } & 00 & $100 \pm 0 a$ & $9.67 \pm 2.25 b$ & $8.23 \pm 1.68 \mathrm{~b}$ & $17.90 \pm 1.23 c$ & $13.0 \pm 0.0 \mathrm{ab}$ \\
\hline & 40 & $100 \pm 0 a$ & $9.46 \pm 0.77 b$ & $3.43 \pm 0.48 \mathrm{a}$ & $12.89 \pm 0.81 b$ & $12.0 \pm 1.0 \mathrm{ab}$ \\
\hline \multirow{3}{*}{$\begin{array}{l}\text { Chromium } \\
\text { (Cr) }\end{array}$} & 80 & $96 \pm 3 a$ & $5.96 \pm 1.17 \mathrm{ab}$ & $3.42 \pm 0.66 \mathrm{a}$ & $8.71 \pm 1.85 a$ & $15.3 \pm 3.9 \mathrm{ab}$ \\
\hline & 120 & $100 \pm 0 a$ & $4.91 \pm 0.59 a$ & $2.98 \pm 0.09 a$ & $7.9 \pm 0.50 a$ & $16.3 \pm 2.0 \mathrm{~b}$ \\
\hline & 160 & $100 \pm 0 a$ & $3.64 \pm 0.91 \mathrm{a}$ & $3.10 \pm 0.32 \mathrm{a}$ & $6.75 \pm 0.70 \mathrm{a}$ & $8.7 \pm 1.3 \mathrm{a}$ \\
\hline
\end{tabular}

Statistical analysis determined by ANOVA. Figs. followed by the same letters in the same column are not significantly different $\mathrm{P}<0.05$ (Duncan Multiple Range Test).

\pm Standard Error

Table 3: Effects of combined treatment of aluminum and chromium on germination and growth of Vigna radiata

\begin{tabular}{ccccccc}
\hline Treatments & $\begin{array}{c}\text { Conc. } \\
(\mathrm{ppm})\end{array}$ & $\begin{array}{c}\text { Germination } \\
\%\end{array}$ & $\begin{array}{c}\text { Root length } \\
(\mathrm{cm})\end{array}$ & $\begin{array}{c}\text { Shoot length } \\
(\mathrm{cm})\end{array}$ & $\begin{array}{c}\text { Seedling length } \\
(\mathrm{cm})\end{array}$ & $\begin{array}{c}\text { Dry biomass } \\
(\mathrm{mg})\end{array}$ \\
\hline Control & 00 & $100 \pm 0 \mathrm{a}$ & $9.67 \pm 2.25 \mathrm{a}$ & $8.23 \pm 1.68 \mathrm{~b}$ & $17.90 \pm 1.23 \mathrm{~b}$ & $13.0 \pm 0.0 \mathrm{a}$ \\
& 40 & $100 \pm 0 \mathrm{a}$ & $8.63 \pm 1.63 \mathrm{a}$ & $3.87 \pm 0.49 \mathrm{a}$ & $12.50 \pm 2.01 \mathrm{a}$ & $12.7 \pm 3.3 \mathrm{a}$ \\
Equally & 80 & $100 \pm 0 \mathrm{a}$ & $5.45 \pm 0.54 \mathrm{a}$ & $8.52 \pm 0.50 \mathrm{~b}$ & $13.97 \pm 1.05 \mathrm{ab}$ & $15.0 \pm 1.0 \mathrm{a}$ \\
Combined & 120 & $100 \pm 0 \mathrm{a}$ & $8.39 \pm 1.03 \mathrm{a}$ & $4.15 \pm 0.45 \mathrm{a}$ & $12.55 \pm 1.42 \mathrm{a}$ & $16.3 \pm 3.3 \mathrm{a}$ \\
$(\mathrm{Al}+\mathrm{Cr})$ & 160 & $100 \pm 0 \mathrm{a}$ & $7.24 \pm 1.13 \mathrm{a}$ & $2.94 \pm 0.14 \mathrm{a}$ & $10.18 \pm 1.10 \mathrm{a}$ & $14.0 \pm 1.0 \mathrm{a}$ \\
\hline
\end{tabular}

Statistical analysis determined by ANOVA. Figs. followed by the same letters in the same column are not significantly different $\mathrm{P}<0.05$ (Duncan Multiple Range Test).

\pm Standard Error

Table 4: Effects of aluminum on germination and growth of Vigna sinensis

\begin{tabular}{ccccccc}
\hline Treatments & $\begin{array}{c}\text { Conc. } \\
(\mathrm{ppm})\end{array}$ & $\begin{array}{c}\text { Germination } \\
\%\end{array}$ & $\begin{array}{c}\text { Root length } \\
(\mathrm{cm})\end{array}$ & $\begin{array}{c}\text { Shoot length } \\
(\mathrm{cm})\end{array}$ & $\begin{array}{c}\text { Seedling length } \\
(\mathrm{cm})\end{array}$ & $\begin{array}{c}\text { Dry biomass } \\
(\mathrm{mg})\end{array}$ \\
\hline Control & 00 & $100 \pm 0 \mathrm{a}$ & $9.55 \pm 0.55 \mathrm{a}$ & $7.69 \pm 2.70 \mathrm{a}$ & $17.25 \pm 2.69 \mathrm{a}$ & $128.0 \pm 65.0 \mathrm{a}$ \\
& 40 & $100 \pm 0 \mathrm{a}$ & $8.75 \pm 2.03 \mathrm{a}$ & $13.09 \pm 2.13 \mathrm{~b}$ & $15.67 \pm 12.40 \mathrm{a}$ & $117.0 \pm 13.0 \mathrm{a}$ \\
$\mathrm{Al}$ & 80 & $100 \pm 0 \mathrm{a}$ & $7.48 \pm 2.55 \mathrm{a}$ & $12.85 \pm 2.16 \mathrm{~b}$ & $20.34 \pm 3.82 \mathrm{a}$ & $116.0 \pm 5.7 \mathrm{a}$ \\
& 120 & $100 \pm 0 \mathrm{a}$ & $7.55 \pm 3.08 \mathrm{a}$ & $11.54 \pm 0.85 \mathrm{~b}$ & $19.12 \pm 3.87 \mathrm{a}$ & $120.0 \pm 12.3 \mathrm{a}$ \\
& 160 & $100 \pm 0 \mathrm{a}$ & $6.48 \pm 2.35 \mathrm{a}$ & $11.57 \pm 1.85 \mathrm{~b}$ & $14.18 \pm 5.01 \mathrm{a}$ & $115.0 \pm 21.0 \mathrm{a}$ \\
\hline
\end{tabular}

Statistical analysis determined by ANOVA. Figs. followed by the same letters in the same column are not significantly different $\mathrm{P}<0.05$ (Duncan Multiple Range Test).

\pm Standard Error

Table 5: Effects of chromium on germination and growth of Vigna sinensis

\begin{tabular}{clccccc}
\hline Treatments & $\begin{array}{c}\text { Conc. } \\
(\mathrm{ppm})\end{array}$ & $\begin{array}{c}\text { Germination } \\
\%\end{array}$ & $\begin{array}{c}\text { Root length } \\
(\mathrm{cm})\end{array}$ & $\begin{array}{c}\text { Shoot length } \\
(\mathrm{cm})\end{array}$ & $\begin{array}{c}\text { Seedling length } \\
(\mathrm{cm})\end{array}$ & $\begin{array}{c}\text { Dry biomass } \\
(\mathrm{mg})\end{array}$ \\
\hline Control & 00 & $100 \pm 0 \mathrm{a}$ & $9.55 \pm 0.55 \mathrm{~d}$ & $7.69 \pm 2.70 \mathrm{ab}$ & $17.25 \pm 2.69 \mathrm{c}$ & $128.0 \pm 64.0 \mathrm{a}$ \\
& 40 & $100 \pm 0 \mathrm{a}$ & $4.94 \pm 0.55 \mathrm{c}$ & $8.67 \pm 0.55 \mathrm{ab}$ & $13.61 \pm 0.79 \mathrm{~b}$ & $118.0 \pm 4.3 \mathrm{a}$ \\
& 80 & $100 \pm 0 \mathrm{a}$ & $3.95 \pm 1.37 \mathrm{bc}$ & $7.03 \pm 1.37 \mathrm{ab}$ & $10.98 \pm 2.24 \mathrm{ab}$ & $122.0 \pm 12.0 \mathrm{a}$ \\
$\mathrm{Cr}$ & 120 & $100 \pm 0 \mathrm{a}$ & $2.47 \pm 0.88 \mathrm{ab}$ & $6.31 \pm 0.88 \mathrm{a}$ & $8.78 \pm 1.76 \mathrm{a}$ & $122.0 \pm 11.0 \mathrm{a}$ \\
& 160 & $100 \pm 0 \mathrm{a}$ & $2 \pm 0.14 \mathrm{a}$ & $9.62 \pm 0.14 \mathrm{~b}$ & $11.63 \pm 0.42 \mathrm{ab}$ & $123.0 \pm 5.7 \mathrm{a}$ \\
\hline
\end{tabular}

Statistical analysis determined by ANOVA. Figs. followed by the same letters in the same column are not significantly different $\mathrm{P}<0.05$ (Duncan Multiple Range Test).

\pm Standard Error 
Table 6: Effects of combined treatment of aluminum and chromium on germination and growth of Vigna sinensis

\begin{tabular}{ccccccc}
\hline Treatments & $\begin{array}{c}\text { Conc. } \\
(\mathrm{ppm})\end{array}$ & $\begin{array}{c}\text { Germination } \\
\%\end{array}$ & $\begin{array}{c}\text { Root length } \\
(\mathrm{cm})\end{array}$ & $\begin{array}{c}\text { Shoot length } \\
(\mathrm{cm})\end{array}$ & $\begin{array}{c}\text { Seedling length } \\
(\mathrm{cm})\end{array}$ & $\begin{array}{c}\text { Dry biomass } \\
(\mathrm{mg})\end{array}$ \\
\hline Control & 00 & $100 \pm 0 \mathrm{a}$ & $9.55 \pm 0.55 \mathrm{c}$ & $7.69 \pm 2.70 \mathrm{a}$ & $17.25 \pm 2.69 \mathrm{~b}$ & $128.0 \pm 64.0 \mathrm{a}$ \\
& 40 & $100 \pm 0 \mathrm{a}$ & $5.93 \pm 1.50 \mathrm{~b}$ & $8.69 \pm 1.34 \mathrm{a}$ & $14.66 \pm 2.61 \mathrm{ab}$ & $118.0 \pm 6.9 \mathrm{a}$ \\
Equally & 80 & $100 \pm 0 \mathrm{a}$ & $2.63 \pm 1.19 \mathrm{a}$ & $6.97 \pm 2.97 \mathrm{a}$ & $9.60 \pm 4.09 \mathrm{a}$ & $96.0 \pm 18.5 \mathrm{a}$ \\
Combined & 120 & $100 \pm 0 \mathrm{a}$ & $3.14 \pm 1.44 \mathrm{a}$ & $8.66 \pm 0.53 \mathrm{a}$ & $11.80 \pm 0.97 \mathrm{a}$ & $133.0 \pm 13.6 \mathrm{a}$ \\
$(\mathrm{Al}+\mathrm{Cr})$ & 160 & $100 \pm 0 \mathrm{a}$ & $3.26 \pm 1.02 \mathrm{a}$ & $6.84 \pm 2.77 \mathrm{a}$ & $10.11 \pm 1.80 \mathrm{a}$ & $110.0 \pm 2.3 \mathrm{a}$ \\
\hline
\end{tabular}

Statistical analysis determined by ANOVA. Figs. followed by the same letters in the same column are not significantly different (Duncan Multiple Range Test).

\pm Standard Error

\section{DISCUSSION AND CONCLUSION}

According to the effects of aluminum and chromium on p an ts. V. radiata and V. sinensis; both of these crops showed no such effect on germination. The seeds of both the species germinated $100 \%$ within few days. After the exposure of these germinated seeds for 10 days to aluminum and chromium singly and in combination, inhibition symptoms and promotive effect were seen. Growth of root was completely inhibited in $V$. sinensis and promoted in $V$. radiate. This is in conformity with the observation of Foy et al., (1978). Asp et al., (1988) found that the growth of shoot and seedlings was mostly enhanced in all the species except in wheat seedlings at aluminum exposure. It means that aluminum was most promotive at low concentration but showed adverse effects at high concentration. Rout et al., (2001) found that aluminum did not affect the seed germination but helped in new root development and seedling establishment. Neogy et al., (2000) found that aluminum toxicity was major deterrent for plants growth in acid soils. They studied the effect of aluminum toxicity on growth of $V$. radiata seedlings. Seeds germination declined with increased metal content while low dosage promoted germination. Aluminum is not regarded as an essential nutrient, but low concentration can sometime increases plant growth in some of the cases Jamal et al., 2006). Aniol, (1984) showed that net root elongation in both tolerant and sensitive cultivars of wheat could be improved by pre incubating roots in solution with lower aluminium levels. Parker, (1995) demonstrated that the roots of wheat cultivars that differ in aluminum tolerance acclimatized quiet quickly after an initial severe decline in root elongation, which lasted from one to several hours after exposure to aluminum. The effect of chromium on both species showed inhibitory effect. Bishoni, (1993) reported that chromium VI supplied, as potassium dichromate did not affect the percentage germination but suppressed the growth of radical and plumule, significantly. Its affect was more pronounced on roots than on the shoots. Hexavalent chromium was present in soil, air, water and sediments. and it is the most toxic form of chromium but this chromium form is converted to non toxic chromium III form and this conversion is done by organic matter present in water and soil. Chromium VI washed down on the soil from air and then converted to chromium III. Thus the chromium does not show any toxicity. However, diverse effect was found in the present experiment because the seeds were germinated and grown in petri plates without using any organic matter which could lower the toxicity by converting chromium VI to chromium III., This resulted in deleterious effect of chromium on the growth of all plants. V. radiata showed the toxicity symptoms at all concentration of both aluminium and chromium. Stem of $V$. radiata became purple, this means that both the metals were toxic to V. radiata but didn't affect the seed germination. Plants require certain amount of metal for their normal growth. Sharma et al., (2000) found that the presence of chromium in the effluent of the tanneries sometimes used by farmers for irrigation purpose. Low concentration may be stimulatory to plant growth while higher concentrations are inhibitory and toxic to plant growth (Sharma et al., 2000).

Root showed exposed to heavy metals showed greater reduction than shoot and seedling. Bishoni et al., (2003) demonstrated that the translocation of chromium from roots to shoots was extremely limited and accumulation of chromium by roots was 100 fold higher than by shoot as found in pea plant. Chromium was found more toxic than aluminum because the magnitude of reduction was high in chromium than aluminum. Karr, et al., (1984) found that the degree to which toxicity symptoms are expressed by plants depends on a number of factors including: amount of 
aluminum and other ions present, amount and form of organic matter and the plant genotype. Both Vigna spp. showed inhibitory effect on the growth as the study was conducted in a complete metal solution and there was no other factor to reduce the toxicity. Hodson and Wilkins (1991) also found that aluminum might react with the silicates present in the cell wall to form aluminoisilicates. Until the metals were present in bound form, it does not affect the plants and when it was found in unbound form it reduced the growth of plant.

\section{REFERENCES}

Aniol, A., (1984). Induction of aluminum tolerance in wheat seedlings by low doses of aluminium in the nutrient solution. Plant Physiol., 75, 551-555.

Asp, H., Bengtsson, B. and Jensen, P., (1988). Growth and cation uptake in spruce (Picea abies Karst.) grown in sand culture with various aluminium contents. Plant Soil, 111, 127-133.

Bishoni, N. R., (1993). Effect of chromium on seed germination, seedling growth and yield of peas. Agric. Ecosyst. Environ., 47, 47-57.

Delhaize, E. and Ryan, P. R., (1995). Aluminum toxicity and tolerance in plants. Plant Physiol 107, 315-321.

Foy, C. D., Chaney, R. L. and Shite, M. C., (1978). The physiology of metal toxicity in plants. Annu. Rev. Plant Physiol., 29, 511-566.

Hodson, M. J. and Wilkins, D. A., (1991). Localization of aluminum in the root of Norway Spurse (Picea abies) inoculated with Paxillus involutus. New Phytol., 118, 273278.

Horst, W. J., Schmohl, N., Kollmeier, M., Baluska, F. and Sivaguru, M., (1999). Does aluminum inhibit root growth of maize through interaction with the cell wall-plasma membrane-cytoskeleton continuum? Plant Soil, 215, 163174.

Jamal, S. N., Iqbal, M. Z. and Athar, M., (2006). Effect of aluminum and chromium on the growth and germination of mesquite (Prosopis juliflora (Swartz.) DC). Int. J. Environ. Sci. Techn., Accepted for publication.

Joshi, U. N., Rathore, S. S. and Arora, S. K., (1999). Effect of chromium on growth and development of cowpea (Vigna unguiculata L.). Indian. J. Environ. Protect., 19, 745-749.
Karr, M.C., Coutinho, J. and Ahlrichs, J. L., (1984). Determination of aluminium toxicity in Indian soils by petri dish bioassays. Proc. Indiana Acad. Sci., 93, 85-88.

Kollmeier, M., Felle, H. H. and Horst, W. J., (2000). Genotypical differences in aluminum résistance of maize are expressed in the distal part of the transition zone. Is reducing basipetalauxin flow involved in inhibition of root elongation by aluminum? Plant Physiol., 122, 945-956.

LeNoble, M. E., Blevins, D. G., Sharp, R. E. and Cumbie, B.G., (1996). Prevention of aluminum toxicity with supplemental boron. I. Maintenance of root elongation and cellular structure. Plant Cell Environ., 19, 1132-1142.

Marienfeld, S., Schmohl, N., Klein, M., Schröder, W. H., Kuhn, A. J. and Horst, W. J., (2000). Localizations of aluminium in root tips of Zea mays and Vicia faba. J. Plant. Physiol., 156, 666-671.

Neogy, M., Datta, J., Roy, A. K. and Mukherji, S., (2000). Studies on phytotoxic effect of aluminum on growth and some morphological parameters of Vigna radiata L. Wilcz. J. Environ. Biol., 23, 411-6.

Parker, D. R., (1995). Root growth analysis: an underutilized approach to understanding aluminium rhizotoxicity. In 'Plant soil interactions at low pH'. (ed. R.A. Date.), 253-323.

Pescod, M. B. and Alka, A.,(1985). Guidelines for water waste reuse in agriculture, FAO Regional seminar on treatment and use sewage effluent for irrigation, Cyprus.

Rana, D. K. and Aery, N. C., (1999). Effect of aluminum stress on the biochemical constituents during early seedling growth of mustard. Bionature, 19, 47-50.

Rout, G. R., Samantara. S. and Dasp, P., (2001). Aluminum toxicity in plants. Agronomie, 21, 3-21.

Saleemi, M. A., (1993). Environmental assessment and management of irrigation and drainage scheme for sustainable agriculture growth. EPA, Lahore, Pakistan

Sharma, A. and Aery, N.C., (2002). Studies on the phytoremidiation of zinc tailings. I. Growth performance of wheat. Vasundhara, 6, 45-50.

Sokal, R.R. and Rohlf, F.J., (1995). Biometry. W.H. Freeman and Co., New York.

Subramani, A., Saravanan, S., Sundaramorty, P. and Lakshmanachary, A.S., (1997). Impact of fertilizer factory effluent on the morphometrical and growth of Vigna mungo L. Pollut. Res., 16, 29-31. 


\section{AUTHOR(S) BIOSKETCHES}

Jamal, Sh. N., B.Sc. (Hons.), M.Sc., is a lecturer in the Department of Botany, City College Karachi, and a Ph.D. research fellow in the Department of Botany, University of Karachi, Karachi, Pakistan. E-mail:shagi_83@hotmail.com

Iqbal, M. Z., B.Sc. (Hons.), M.Sc., Ph.D., is professor and chairman, Department of Botany, University of Karachi, Karachi, Pakistan. E-mail: mziqbalbotuokpk@yahoo.com

Athar, M., M.Sc., M.Phil., Ph.D., D.Sc., is a Research Scientist with the State of California, Department of Food and Agriculture, Sacramento, California, USA. E-mail: atariq@cdfa.ca.gov

\section{This article should be referenced as follows:}

Jamal, S. N., Zafar Iqbal, M. and Athar, M. (2006). Effect of aluminum and chromium on the germination and growth of two Vigna species. Int. J. Environ. Sci. Tech., 3 (1), 53-58. 